\title{
Modality of possibility and the system of means to express it in Spanish
}

\author{
Angelica P. Alexandrova
}

\section{DOI: 10.18355/XL.2017.10.03.27}

\begin{abstract}
The article deals with the category of modality in the Spanish language and concentrates on modality of possibility. It aims at describing the semantics of possibility and gives the system for expressing different sub-meanings of possibility in Spanish. It analyzes how the modality of possibility is described within the framework of the functional-semantic approach which is realized in functional grammar. Three works by Gabriel García Márquez were a practise material to achieve the purpose of the paper. The model of the functional semantics of an utterance allowed getting basic formulae which reflect standard ways for communication of the modality of possibility in the utterance and standard situations behind them. The nucleus of the functional-semantic field of possibility in the Spanish language is "the internal inherent possibility". The examples which were selected by random sampling indicate that the system of expressing the modal meaning of possibility in the Spanish language has a strong verbal dominant.
\end{abstract}

Key words: modal meaning of possibility, sentential form, determining factor, functional grammar, modal nouns

\section{Introduction}

No other category except the category of modality has caused so different and controversial points of view on its linguistic nature and content of its particular meanings. The majority of researches include in its content the meanings which are diverse in their nature and functionality, thus, the category of modality loses any definiteness. The continuous discussion of a number of multi-aspect relations, which are associated with the notion of modality, reflects the reality of the existence of a complex of language meanings, between which there are some connections. However, the commonality between the meanings under consideration is combined with fargoing differences.

The well-known characteristic of modality is an attitude of the utterance content to the reality, which is established by a speaker. However, the understanding of modality, which is formulated in this way, is very vague. Modality is a language universal; it is one of the major language categories. Linguists, who are engaged in the study of modality, are concerned about the issues which are connected with determining the essence of modality category as one of the main predicative categories of the sentence, analyzing its content structure and identifying the language means of expressing the modal meanings. The main differences relate to the semantic volume of this "super-category", which, respectively, has a very wide interpretation (V. Vinogradov, P. Adamec, Ch. Bally, É. Benveniste, etc.), and more narrow understanding - T. Lomtev, L. Yermolaeva, G. Zolotova, V. Bondarenko, V. Panfilov, I. Golovin, L. Durovich, V. Shabalina, J. Popela, B. Panzer, etc. (Alexandrova, 2008a).

Taking into account some research papers, the linguists (L. Biryulin, E. Kordi) managed to make a list of those language phenomena that relate to modality. The common semantic characteristic of the "modal objects" is a "speaker's point of view" (Theory of functional grammar (TFG), 1990). They distinguish only six types of meanings. 
(1) Speaker's evaluation of the utterance content from the point of view reality/ unreality (supposition, etc.).

(2) The evaluation of the situation, which is denoted in the utterance, from the point of view of its possibility, necessity or desirability.

(3) Speaker's evaluation of the degree of their certainty in the reported.

(4) Speaker's target setting or communicative function of the utterance.

(5) Meanings of approval / denial which reflect the presence / absence of objective relations between objects, signs, events, which are referred to in the sentence

(6) Emotional and qualitative evaluation of the utterance content.

The purpose of the article was to identify the semantic structure of modality of possibility, and means of its expression in the Spanish language, and submeanings of modality of possibility which are dominant in the text.

\section{Literature review}

This part of the paper focuses on the main approaches to the category of modality in Spanish. The differentiated approach to the category of modality is not characteristic of the majority of hispanists in the native linguistics (S. Kanonich, V. Firsov, I. Patrushev). Not large sections on the category of modality (Angulo, 2003; Hualde et al 2010; Alkire \& Rosen, 2010; Kim, 2000; Amado \& Ureña, 1938; Bosque, 1990; Rojo, 1988; Spisiakova, 2016) lead to the conclusion that in the foreign hispanistics the development of the problem of modality is mainly conducted in two directions:

1. Verbal mood undergoes a detailed analysis; most scholars identify it with the category of modality, and only some researchers consider it to be one of the grammatical means of this category;

2. Interpretation of modality on the syntactic level is reduced, as a rule, to singling out so-called modal types of sentences, which is performed simultaneously on several different grounds.

While describing grammatical semantics of certain verb forms, in different syntactic conditions the concepts of possibility "posibilidad", "eventualidad" probability "eventualidad", "probobilidad", and assumption, doubt "suposición", "hipótesis", "conjetura", "duda" are confused. At the same time, some linguists, who consider modal relations at the syntactic level (Sliačanová, 2011), classify sentences according to the nature of speaker's attitudes to the utterance, and name the sentence of possibility "oraciónes de posibilidad" and the sentence of doubt "oraciónes dubitativos" as independent modal types of sentences.

In domestic linguistics, modality is presented as a functional-semantic category which comprises a system of grammatical forms of verbal mood, as well as syntactic and lexical means of expressing the utterance attitude to reality. In this regard, it is interesting to consider the functional approach to the description of the category of modality.

\section{Methods and material}

The description model of functional-semantic fields, which is developed in the framework of functional grammar, can help to identify the semantic structure of modality of possibility, and means of its expression in the Spanish language, and submeanings of modality of possibility which are dominant in the text.

Functional grammar considers certain models, which are expressed by appropriate means for conveying certain meanings. It is interesting to have a look at the apparatus for describing functional-semantic fields, which is determined by certain parameters. It is important to note that in functional grammar the linguists deduced a set of parameters for interpreting the modal fields when analyzing utterances (TFG, 
1990; Belyaeva, 1977; 1985; Zeitlin, 1985). All current works use the notion of a sentential form, thus, it is necessary to derive sentential forms, which express the basic modal meanings.

So, let us turn to the model of functional semantics of the utterance, which allows deducing the basic formulae that reflect typical means for expressing the modal meaning of possibility in the utterance and its typical situations. Any potential situation is determined by some determining situation, which implies a factor causing the realization of the connection of the subject of an objective situation and its characteristic. Logically, a determining situation is a basis for realizing a potential situation, and the causal relationship between them can be expressed in various ways (TFG, 1990: 125).

The initial sentential form for possibility situations is ' $\mathrm{X}$ can do $\mathrm{P}$ '.

While introducing an explicit indication to a determining factor (DF) into the formula, we get:

$\begin{array}{ll}\text { at moment } \mathrm{t} 1 & \begin{array}{c}\text { there are conditions } \mathrm{Z}, \\ \text { which cause, }\end{array} \\ \text { at moment } \mathrm{t} 1 / \mathrm{n} & \mathrm{X} \text { can do } \mathrm{P}\end{array}$

Particularization of the nature of the conditions, which make up determining factors, allows obtaining more detailed formulae, which correspond to a set of semantic types of possibility situations that are singled out in the theory of functional grammar to describe these fields. Situations of internal unacquired (inherent) possibility: "DF is in the subject itself (we denote it as $X$ ), representing its internal characteristics" (we denote them as M) (TFG, 1990:131; Alexandrova, 2008: 95-97). In this case, the properties $M$ of subject $X$ cause realization $P$ :

There are conditions $\mathrm{Z}$ :

$\mathrm{X}^{\prime}$ belongs to class $\mathrm{X}$, and

$\mathrm{X}^{\prime}$ has inherent properties $\mathrm{M}$ (physical, mental, and so forth.)

such that

M causes:

$\mathrm{X}^{\prime}$ can do $\mathrm{P}$.

In this case, it is possible to single out qualifiers such as the nature of $X$, the nature of inherent properties of $X$, namely:

1) physical properties of a substance (as $X$ is a material inanimate object or realia), for example:

Dicen que el avion puede llegar a Europa en una noche.

Unos documentos de esa índole no pueden pasar inadvertidas para ningún funcionario - dijo el coronel.

Era imposible arrancar una tira de ese caucho sólidamente fundido a la tela.

2) physical properties of a human / living creature:

Pero nadie pudo llevarse los documentos para su casa - dijo el coronel.

- ¿No puede caminar? - me dijo el hombre.

Y yo, acostado en mi litera, sin poder dormir a causa de los movimientos de la nave, me sentía seguro con sus palabras.

Traté de resistir en el fondo de la balsa, pero no fue posible.

3) person's mental properties, their system of views and beliefs:

Cuando me pareció que era imposible resistir, faltaban 20 minutos para las nueve de la noche.

XLinguae Journal, Volume 10 Issue 3, June 2017, ISSN 1337-8384 
"Puede ser una buena corazonada", replicó Alvaro.

Situations of internal acquired possibility are:

4) person's abilities, skills, knowledge:

Creo que un viejo marinero que haya viajado por todo el inundo, puede saber en qué mar se encuentra por la manera de moverse el barco.

....Luis Rengifo un hombre fuerte, un buen nadador bien alimentado que no pudo alcanzar la balsa a dos metros de distancia.

In situations of external possibility, the determining factor is out of the subject. In external possibility situations, the determining factors are conditions of:

A) non-deontic nature:

A1) a situation and external circumstances which it determines:

Para entonces Agustín habrá cumplido su año y podremos ir al cine.

Pero si esta muy ocupado puedo venir mas tarde.

Ante la proximidad de la fecha de partida, sin poder deshacerme de mis preocupaciones, tomé una determinación: tan pronto como llegara a Cartagena abandonaría la marina.

A2) the objective laws of the universe:

Es imposible que la noche sea tan larga como el día.

En la agonía, un pez puede saltar más alto y más lejos que nunca.

B) deontic nature:

standards

B1) the norms of society, namely, service, legal, social and ethical

society:

that spread to the subject's area because he or she belongs to a particular

Es posible que por el interés de ganarse la plata lo resuelvan antes de enero - dijo, y se convenció a sí mismo.

B2) speaker's will:

Puedes decir a alguien que te la saque a maquina.

Speaking about the means for expressing modal meaning of possibility in the Spanish language, it should be noted that the system of means of this modal meaning in Spanish has a strong verbal dominant (Alexandrova, 2010). The examples from three works by Gabriel García Márquez, the Colombian writer, journalist, publisher, political activist and Nobel Prize in Literature winner, were used for the practical analysis: "One Hundred Years of Solitude" (Cien años de soledad), "No One Writes to the Colonel" (El coronel no tiene quien le escriba), "The Story of a Shipwrecked Sailor" (Relato de un náufrago). These examples were obtained by random sampling.

Most of the examples that express different sub-meanings of the modal meaning of possibility in the Spanish language, illustrate the use of the modal verb poder, for example: Dicen que el avion puede llegar a Europa en una noche. However, the cases of the use of adjectives posible and imposible were rather frequent: Traté de resistir en el fondo de la balsa, pero no fue posible./ Era imposible arrancar una tira de ese caucho sólidamente fundido a la tela.

The analysis of the selected examples also revealed the use of such constructions as sin poder and para poder: Sin poder disimular la repugnancia, arrojé el pedazo que tenía en la boca y permaneci largo rato inmóvil, con aquel repugnante amasijo de plumas y huesos sangrientos en la mano./ Yo sentía una gran admiración por un reportero que se disfrazaba de médico para poder entrar en un 
hospital militar; Pensaba dormir tan pronto como entregara la guardia, para poder divertirme esa noche en tierra firme, después de ocho meses de ausencia.

There were cases of the use of the subjunctive mood: Si yo pudiera decir lo mismo./ "Si Agustín tuviera su año me pondría a cantar". Taking into account the specificity of the noun as a part of speech to name any phenomenon, I analyzed the empirical material with an attempt to select examples, which illustrate the use of nouns with modal semantics of possibility, for further analysis.

The very existence of modal nouns in the language is a well-known fact. Modal nouns are secondary from the point of view of the language evolution, so most of them are derived words. Nouns with a modal component are the so-called syntactic derivatives, correlative with the corresponding verbs, adjectives, which are the primary specialized indicators of modality (Fateeva \& Alexandrova, 2002).

Thus, the system of nouns with modal semantics is formed in the language as a kind of lexical projection of the primary system of relations of the form "a modal modifier + a referential situation represented in the proposition," which are expressed in the utterance. The classical tradition of studying the system, the core of which is formed by the mood of the verb-predicate and its lexical modal modifiers - modal verbs, was built, as it is known, in line with considering specialized modality indicators of the sentence to ensure its functioning as an utterance. Nominal forms of expressing modal meanings do not have their place in such a system, of course; their functional purpose is a vector that is not focused "on" an utterance as the main sphere of application, but rather goes "from" it: in the direction of "isolating generalization" of more significant modal meanings, and in the direction of their effective use for modal clarification of descriptive semantics of other types of nonpresentive names: the names of certain classes of extralinguistic situations, physical and mental states, qualities, properties, relations. However, during the analysis of these three works, there were not a large number of examples, demonstrating the use of modal nouns with the modal meaning of possibility that could give rise to describe them and to determine their status in the system of means for expressing the modal meaning under this study.

\section{Results}

After analyzing the examples, which were singled out by the method of random sampling, it was possible to find out what sub-meanings of possibility were dominant in the text:

$$
\begin{aligned}
& \text { internal unacquired (inherent) possibility - 37.66\%; } \\
& \text { internal acquired possibility - } 10.39 \% \text {; } \\
& \text { external non-deontic possibility }-40.26 \% \text {; } \\
& \text { external deontic possibility }-11.69 \% \text {. }
\end{aligned}
$$

The obtained results can be compared with data obtained in the analysis of the modal semantics of the nouns in the Russian and English languages. Nouns with modal meaning of possibility in the English language make up 60 words, 15 of them are those with the meaning of external possibility, and 47 nouns express the meaning of internal possibility. There is an obvious advantage of internal possibility, which in percentage is the following: internal possibility is $80 \%$ and, respectively, internal possibility is $20 \%$ (Alexandrova, 2008a; Alexandrova, 2008b).

If we compare these data with the data that E.I. Belyaeva obtained in the analysis of the functional-semantic fields of modality, in particular, modality of possibility in English, we can see a completely different picture, as it demonstrates a considerable advantage of external possibility (Belyaeva, 1985), that is what the analysis of the examples in Spanish shows (Gutierrez, 2014). 


\section{Discussion}

As I have noted previously, the insufficient number of examples that illustrate the use of nouns with the modal component 'possibility', do not allow, at this stage of the study, drawing conclusions about the quantitative composition of absolutely modal nous in the Spanish language and their homogeneity/nonhomogeneity.

This suggests that the nouns we are interested in, have the same division that is typical of the system of the primary means to express this type of the meaning, which are described in the framework of functional grammar.

\section{Conclusions}

For the present, there is insufficient clarity about the boundaries of the category of modality, its internal division and the basic semantic types. The paper presents the preliminary results of the study. They are largely due to the fact that the conducted study was based only on about one hundred examples. It is likely that the involvement of a more representative number of examples will allow getting a comprehensive system of means to express the modal meaning in the Spanish language, including the nominative means of expression - nouns containing a modal seme in their semantic structure. A detailed classification of different means for expressing different sub-meanings of possibility will be the subject for further research.

\section{Bibliographic references}

ALEXANDROVA, A.P. 2008b. Modal'nye sushhestvitel'nye so znacheniem vozmozhnosti $\mathrm{v}$ anglijskom i russkom jazykah. Uchenye zapiski Orlovskogo gosudarstvennogo universiteta. № 1. pp. 47 - 51. ISSN 1998-2720

ALEXANDROVA, A.P. 2008a. Modal'nye sushhestvitel'nye v jazyke :na materiale russkogo i anglijskogo jazykov (Thesis of the Cand. Sci.). Orel: Orel State University. ALEXANDROVA, A.P. 2010 Modal'nost' vozmozhnosti v ispanskom. Uchenye zapiski Orlovskogo gosudarstvennogo universiteta. № 3(37) part II. pp. 74 - 76. ISSN 1998-2720

ALKIRe, T. - ROSEN, C. 2010. Romance Languages. Cambridge : Cambridge University Press. ISBN 978-0-521-71784-7

AMADO, A. - URENA P.H. 1938. La Gramática Castellana. Buenos Aires: Losada. ANGULO, F.A. (2003). Gramática de la Lengua Castellana. Madrid: Real Academia Española.

BELYAEVA, E.I. 1977. K probleme leksiko-grammaticheskih polej v jazyke : (Na materiale mikropolej vozmozhnosti i vynuzhdennosti v anglijskom i russkom jazykah) (Thesis of the Cand. of Sci.). Voronezh: Voronezh State University.

BELYAEVA, E.I. 1985. Funkcional'no-semanticheskie polja modal'nosti v anglijskom i russkom jazykah. Voronezh: Voronezh State University.

BONDARKO, A.B. (Ed.) 1990. Teorija funkcional'noj grammatiki. Temporal'nost'. Modal'nost'. Leningrad: Nauka. ISBN 5-02-028005-4

BOSQUE, I. (Ed.) 1990. Tiempo y Asoecto en Español. Madrid : Cátedra. ISBN 978843-760946-1

FATEEVA, E.D. - ALEXANDROVA, A.P. 2002. Modal'nye sushhestvitel'nye v jazyke. Orel: Language and communication. № 9. pp. 46 - 57. ISBN 978-5-99290373-7

GUTIERREZ, R.E. 2014. Metonymy in Spanish word formation: A token analysis. XLinguae Journal. 7(4). pp. 83-90. ISSN 1337-8384

HUALDE, J.I. - OLARREA, A. - ESCOBAR A.M. - TRAVIS C.E. 2010. Introducción a la lingüística hispánica. Cambridge : Cambridge University Press. ISBN 978-0-521513982 
KIM, H.S. (2000) Tiempo y temporalidad en la Lengua Española (Tesis doctoral). Madrid : Universidad Complutense de Madrid.

ROJO, G. 1988. Temporalidad y Aspecto en el Verbo Español. Lingúistica Española Actual. № 10/2. pp. 195 - 216. ISSN 0210-6345

SLIACANOVA, V. 2011. An approach to the problems of appreciative suffixes in the current Spanish [Una aproximación a los problemas de la sufijación apreciativa en el español actual]. XLinguae Journal. 4(2). pp. 17-21. ISSN 1337-8384

SPISIAKOVA, M. 2016. The contrastive analysis of the use, meaning and connotations of the colors in the Slovak and Spanish language. XLinguae Journal. 9(3). pp. $104-128$. ISSN 1337-8384

ZEITLIN, S.N. 1985. Some types of modal situations in the modern Russian language. In A.V. Bondarko et al (Eds.) Functional analysis of grammatical aspects of the language. Leningrad: LGPI. pp. $16-25$.

Words: 3157

Characters: 20532 (10 standard page)

Assoc. Prof., Angelica P. Alexandrova, Cand. Sci. (Philology),

Department of English Philology

Orel State University

95, Komsomolskaya Str., 302026, Orel,

Russia

angelica.p.alexandrova@yandex.ru 